Functional

Ecology 1995

9, 667-676

\section{Gene by environment interaction: effects of a single gene and social environment on reproductive phenotypes of Fire Ant queens}

\author{
L. KELLER* and K. G. ROSS ${ }^{\dagger}$ \\ *Institut de Zoologie et d'Ecologie Animale, University of Lausanne, BB, 1015 Lausanne and Zoologisches \\ Institut, Bern University, Ethologische Station Hasli, 3032 Hinterkappelen, Switzerland and $\dagger$ Department of \\ Entomology, University of Georgia, Athens, GA 30602-2603, USA
}

\section{Summary}

1. The gene $P g m-3$ (or a closely linked gene) influences the phenotype and reproductive success of queens in multiple-queen (polygynous) colonies but not single-queen (monogynous) colonies of the Fire Ant Solenopsis invicta.

2. We investigated the mechanisms of differential phenotypic expression of Pgm-3 in these alternate social forms. Mature winged queens with the homozygous genotype $P g m-3^{a / a}$ averaged $26 \%$ heavier than queens with the genotypes $P g m-3^{a / b}$ and $P g m$ $3^{b / b}$ in the polygynous form. Heterozygotes were slightly heavier $(2 \%)$ than $P g m-3^{b / b}$ queens in this form, demonstrating that the allele $P g m-3^{a}$ is not completely recessive in its effects on weight.

3. There was no significant difference in weight among queens of the three Pgm-3 genotypes in the monogynous form, with the mean weight of monogynous queens slightly greater than that of polygynous $P g m-3^{a / a}$ queens. Differences in weight between queens of the two social forms and among queens of the three genotypes in the polygynous form are not evident at the pupal stage and thus appear to develop during sexual maturation of the adults. This suggests that some component of the social environment of polygynous colonies inhibits weight gains during queen maturation and that $P g m-3^{a / a}$ queens are relatively less sensitive to this factor.

4. To test whether the high cumulative queen pheromone level characteristic of polygynous colonies is the factor responsible for the differential queen maturation, we compared phenotypes of winged queens reared in split colonies in which pheromone levels were manipulated by adjusting queen number. Queens produced in colony fragments made monogynous were heavier than those produced in polygynous fragments, a finding consistent with the hypothesis that pheromone level affects the reproductive development of queens. However, genotype-specific differences in weights of queens were similar between the two treatments, suggesting that pheromone level was not the key factor of the social environment responsible for the gene-environment interaction.

5. To test whether limited food availability to winged queens associated with the high brood/worker ratios in polygynous colonies is the factor responsible for this interaction, similar split-colony experiments were performed. Elevated brood/worker ratios decreased the weight of winged queens but there was no evidence that this treatment intensified differential weight gains among queens with different Pgm-3 genotypes. Manipulation of the amount of food provided to colonies had no effect on queen weight.

6. The combined data indicate that cumulative pheromone level and brood/worker ratio are two of the factors responsible for the differences in reproductive phenotypes between monogynous and polygynous winged queens but that these factors are not directly responsible for inducing the phenotypic effects of $P g m-3$ in polygynous colonies. 


\section{Introduction}

Organismal phenotypes are produced by complex interactions between genetic and environmental information. Phenotypic differences among individuals may affect capabilities for survival and reproduction and, therefore, the rates of transmission of different genes to subsequent generations. Thus a fundamental problem in evolutionary biology is to understand how genetic differences may, in concert with environmental factors, affect the phenotype of an organism and, ultimately, its reproductive success (e.g. Bradshaw 1965; Via \& Lande 1985; Hedrick 1986; WestEberhard 1989; Wade 1990; Moran 1992; Pfennig 1992a,b; Stearns 1992; Pfennig \& Collins 1993).

An unusual gene by environment interaction has been discovered recently in the Fire Ant Solenopsis invicta Buren (Keller \& Ross 1993a). Two distinctive social forms exist in this species; the monogynous form, in which colonies are headed by a single reproductive queen, and the polygynous form, in which colonies are headed by multiple reproductive queens. A single gene designated as Pgm-3 (or a closely linked gene referred to as $P g m$ - 3 hereafter) has been shown to influence strongly the phenotype and reproductive success of queens in the polygynous form (Ross 1992; Keller \& Ross 1993a). Young polygynous queens with the homozygous genotype $P g m-3^{a / a}$ are prevented from becoming egg-layers by the workers in their colonies; the workers invariably destroying such queens as they initiate reproduction (Keller \& Ross 1993a). This differential survival and recruitment of new queens of different genotypes is associated with phenotypic differences (Keller \& Ross 1993a); young, non-reproductive, winged queens with the genotypes $P g m-3^{a / b}$ and $P g m-3^{b / b}$ weigh less, shed their wings less frequently (a behaviour associated with the onset of reproduction) and become less fecund than $P g m-3^{a / a}$ queens. In contrast, a queen's genotype does not affect her phenotype or her probability of survival (or reproduction) in the monogynous form of this ant (Ross 1992; Keller \& Ross 1993a).

The lack of observable differences in phenotype and reproductive success among queens of different $P g m-3$ genotypes in the monogynous form suggest that the effects of this gene on reproductive competence are dependent on the social environment. Differences in social environment between the two forms are known to influence the reproductive development of young queens. Newly emerged queens of the two forms are indistinguishable in weight but within a few weeks monogynous winged queens become $40 \%$ heavier, on average, than polygynous queens, mainly because of a greater accumulation of fat reserves (Keller \& Ross 1993b). The extent of these reserves, which is a marker of reproductive development (Keller \& Passera 1989; Passera \& Keller 1990), has been shown by cross-fostering studies to be dependent largely on the number of egg-lay- ing queens present in the colony in which queens mature (Keller \& Ross 1993b). The pace at which mature winged queęns actually initiate reproductive activity when removed from the inhibitory influence of queen pheromones also depends on the number of egg-laying queens that were present during their maturation period. Virtually all monogynous winged queens isolated from their parent colonies shed their wings and begin laying eggs within 3 days, whereas fewer than $15 \%$ of polygynous queens do so under the same circumstances (Fletcher, Cherix \& Blum 1983; Keller \& Ross 1993a; Vargo \& Laurel 1994).

This study investigates the effects of the social environment on the reproductive phenotype of winged $S$. invicta queens and attempts to identify the specific component of the social environment that interacts with $P g m$-3 genotype to influence queen phenotype in the polygynous form. Queen weight is used to index reproductive development because of its ease of measurement and its strong correlation with other measures of reproductive activity (Keller \& Ross 1993a). We first examined the weights of queen pupae and mature winged queens to consider whether phenotypic differences between $P g m-3^{a / a}$ queens and the others arise during the period of adult sexual maturation or during the larval stage. Next, we manipulated colonies to identify both the environmental factors that act independently of genotype to influence the phenotypes of winged queens in the two social forms as well as the factors involved in the gene by environment interaction that influences queen phenotypes. Several lines of evidence suggest that pheromone production by multiple reproductive queens results in higher cumulative pheromone levels in polygynous colonies than in monogynous colonies (see Fletcher 1986; Vargo 1990). These higher colony pheromone levels are associated with the production both of fewer new reproductives (Vargo \& Fletcher 1986a,b, 1987 ) and smaller workers (Greenberg, Fletcher and Vinson 1985; Porter 1992) in polygynous than in monogynous colonies. Queen-produced pheromones in Fire Ants also appear to reduce the fecundity of other queens and to inhibit winged queens from shedding their wings and initiating reproduction (Fletcher \& Blum 1981; Vargo \&. Fletcher 1986a,b; Vargo 1992; Vargo \& Laurel 1994). We therefore compared phenotypes of winged queens produced in experimental colonies in which pheromone levels were manipulated by adjusting queen number. If higher pheromone levels are responsible for the differential effects of the genotypes in polygynous colonies, then a greater weight difference among winged queens of different $P g m-3$ genotypes is expected in colony fragments with multiple reproductive queens than in colony fragments with single queens. Such a pattern would show that the expressivity of $P g m$-3 (the magnitude of its effects on queen weight and reproductive physiology) is influenced by queen number and, presumably, the pheromone level in the natal colony. 
669

Gene-

environment

effects on Fire

Ant phenotypes
We also investigated the hypothesis that the overall lower weight of polygynous winged queens and the differential effects of the Pgm-3 genotypes in polygynous colonies are the result of limited food availability to maturing queens of this form. Polygynous colonies may experience such food limitation because of the apparently high brood/worker ratios compared to colonies of the monogynous form (Greenberg et al. 1985; Porter et al. 1991), an observation that is also consistent with the smaller size of workers in polygynous colonies. Differences in genotype at phosphoglucomutase loci have been shown to interact with feeding regime to affect developmental time in Flour Beetles (Riddle, Iverson \& Dawson 1983) and liver glycogen levels in Field Mice (Leigh Brown 1977), making appealing the hypothesis that it is the dietary constraints in polygynous Fire Ant colonies that are necessary for a phenotypic effect of $P g m-3$ to be manifested. This hypothesis that diet affects Pgm-3 expressivity was tested by comparing weights of winged queens of the three Pgm-3 genotypes reared in colony fragments with different feeding regimes as well as in colony fragments in which the actual brood/worker ratios were manipulated.

Finally, the large data set generated in this study was found to be appropriate to investigate further the question of whether $P g m-3^{a}$ acts as a completely recessive allele with respect to its effects on queen reproductive phenotype in the polygynous form.

\section{Materials and methods}

\section{SAMPLING OF QUEEN PUPAE}

Polygynous colonies were collected in May and June 1994 from Walton County, GA, USA. Colonies were taken to the laboratory immediately, where the ants were removed from the soil by flooding (Jouvenaz et al. 1977). Colonies subsequently were maintained in the laboratory at $30 \pm 1^{\circ} \mathrm{C}$ and $60-80 \%$ r.h. in a 14L:10D regime. The ants were provided with water in stoppered glass tubes and fed mixed-vegetable baby food and frozen crickets. Queen pupae were collected from 18 polygynous colonies (11-30 pupae per colony). Only white pupae with pigmented eyes were sampled in order to obtain individuals of similar age. The pupae were weighed and their genotypes at Pgm3 were determined by means of gel electrophoresis (Ross 1992; Shoemaker, Costa \& Ross 1992; Keller \& Ross 1993a).

\section{SAMPLING OF MATURE WINGED QUEENS}

The mature winged queens collected for this study were taken from the surfaces of their colonies as they (c) 1995 British Ecological Society, Functional Ecology, 9, 667-676 colony) in Walton County (see Greenberg et al. 1985 and Vargo \& Fletcher 1987 for criteria that distinguish the two types of colonies). No obvious ecological differences exist between the habitats occupied by the alternate social forms in these two nearby counties. Furthermore, no genetic differentiation exists between the two forms at these localities at markers not under strong differential selection, apparently because of extensive gene flow between them (Ross 1992; Ross \& Shoemaker 1993; Ross \& Keller 1995). Because $S$. invicta queens mate with a single haploid male (Ross \& Fletcher 1985; Ross et al. 1993), examination of the distributions of genotypes at multiple loci allows ready confirmation of the social organization of a colony (Ross 1993). Determination of genotypes of winged queens at four polymorphic loci (Est4, G3pdh-1, Pgm-1 and Pgm-3) by electrophoresis (Shoemaker et al. 1992; Ross 1993) confirmed that genotype distributions in the 22 putative monogynous colonies were consistent with those expected in colonies containing one singly-mated queen, whereas those in almost all of the putative polygynous colonies were not. To compare the weight of $P g m-3^{a / a}$ and $P g m-3^{a / b}$ winged queens in the monogynous form, we wished to obtain data from the maximum number of colonies headed by $P g m-3^{a / b}$ queens mated to $P g m-3^{a}$ males (these colonies produce $P g m-3^{a / a}$ and $P g m-3^{a / b}$ daughters in a 1:1 ratio). Therefore, we determined the Pgm-3 genotypes of six winged queens from each of the 22 monogynous colonies in a preliminary survey. From each of the six colonies that were identified as having the appropriate mating types, additional winged queens (up to 24 per colony) were weighed and their Pgm-3 genotypes determined. Because only relatively few $P g m-3^{a / a}$ winged queens are found in polygynous colonies (Ross 1992; Keller \& Ross 1993a), and because it is impossible to identify easily beforehand which colonies have the highest proportions of such queens, we weighed and determined the $P g m-3$ genotypes of all polygynous winged queens collected $(n=857)$.

\section{DEVELOPMENT OF QUEENS IN MONOGYNOUS AND POLYGYNOUS COLONY FRAGMENTS}

Polygynous colonies with large numbers of sexual brood were collected in May 1993 from Walton County. Colonies were established immediately in the laboratory as described above. Nineteen polygynous colonies that contained at least 16 egg-laying queens and numerous queen pupae were selected for this experiment. Each colony was sieved (1.4 mm mesh) to remove all sexual forms (including winged adults, sexual pupae and large sexual larvae) and was then divided into halves, one containing a single reproductive queen and the other containing 15-20 of the remaining reproductive queens. Worker brood, adult workers and old queen pupae (recognized by their dark cuticle) were divided evenly between the halves queens were collected from 22 colonies (20-30 queens per colony) in Clarke County, GA, and polygynous queens from 35 colonies (14-84 queens per 
(C) 1995 British Ecological Society, Functional Ecology, 9, 667-676 of each colony. All queen pupae metamorphosed into adult winged queens within 3 days after the colony splits were made. The colonies were maintained for 10 additional days, after which time all winged queens (which were then 10-13 days of age and thus mature: Keller \& Ross 1993b) were collected to determine their weights and Pgm-3 genotypes.

\section{DEVELOPMENT OF QUEENS IN COLONIES WITH DIFFERENT BROOD/WORKER RATIOS AND FOOD LEVELS}

Seventy-three polygynous colonies collected in May and June 1994 from Walton County were established immediately in the laboratory. Nineteen polygynous colonies containing a minimum of 12 egg-laying queens and large numbers of queen pupae were selected for this experiment. Each colony was sieved to remove all sexual forms and then was divided into three fragments. Queens, adult workers and old queen pupae were divided evenly among the fragments of each colony (four to six egg-laying queens per fragment). Each of the three fragments was randomly assigned to one of the following treatments: 'high brood' (a high brood/worker ratio), 'food limited' and 'control'. Sixty per cent of the worker brood of each source colony was provided to the 'high brood' fragment and the remaining $40 \%$ was divided equally between the other two fragments. 'High brood' fragments thus contained three times more brood than the corresponding 'food limited' and 'control' fragments at the onset of the experiment. Furthermore, the 'high brood' fragments received daily infusions of eggs and young larvae from polygynous colonies that were maintained in the laboratory but were not part of the experiment. The quantity of brood introduced daily into each of these fragments was about $15 \%$ of the amount of brood already present (this quantity was chosen so that the amount of brood in the 'high brood' fragments remained about three times that in the "control' fragments during the course of the experiment). 'High brood' and 'control' fragments were fed ad libitum. 'Food limited' fragments were given the same standard diet (above) but the daily ration was approximately one-third the amount that a colony of equivalent size would normally consume. This resulted in a significant decrease in the amount of brood in these colonies during the course of the experiment. Within 3 days after the colony splits were made, all queen pupae had metamorphosed into adults. The colonies were maintained for an additional 10 days, after which time all winged queens were collected to determine their weights and Pgm-3 genotypes.

\section{STATISTICAL ANALYSES}

A Kolmogorov test showed that the weight distributions of queen pupae and winged queens did not depart significantly from normality. Therefore, analy- ses of variance were used to compare weights. Several studies have shown that the colony of origin of queen pupae has a significant effect on the weights of these pupae and the winged queens derived from them (Keller \& Ross 1993a,b, unpublished data). Therefore, we controlled for the variance associated with colony of origin by including this factor in the ANOVAs.

To compare the weights of queen pupae and of mature winged queens collected as they departed on mating flights, we used three-way nested ANOVAs, with colonies nested in the social form (monogynous or polygynous) and genotype and social form as the other independent factors. Two out of the 1084 winged queens departing on mating flights had abnormally low weights (more than $6 \mathrm{SD}$ below the average weight in their colonies) and therefore were not included in the analyses.

Previous studies (Keller \& Ross 1993a,b, unpublished data) also have shown that the colony in which adult queens mature may exert a significant influence on queen weight. Although each source colony was divided into fragments initially identical in worker number and brood composition (except for the treatment in which brood/worker ratio was intentionally altered), we used the mean weight of a given genotype in each fragment in the ANOVAs for all split-colony experiments to avoid problems stemming from possible non-independence of the data from single fragment.

We weighed $P g m-3^{a / b}$ and $P g m-3^{b / b}$ winged queens collected from polygynous colonies in the field and produced in the laboratory colony fragments assigned to the different experimental treatments to determine whether the allele $P g m-3^{a}$ is completely recessive in its effects on queen weight. We compared the weights of winged queens of these two genotypes separately for each treatment, using two-way ANOVAs to control for the effects of colony of origin and colony where the individuals were raised. Means were judged to be significantly different when $P<0.05$.

\section{Results}

\section{EFFECTS OF SOCIAL FORM AND PGM-3 GENOTYPE}

A three-way nested ANOvA was used to compare the weights of mature winged queens from field colonies (see Materials and methods). As expected from previous studies (Keller \& Ross 1993a,b), the colony of origin had a significant effect on the weights of these queens $(F=11.45 ; \mathrm{df}=55 ; P<0.001)$. There was also a significant effect of the social form, with winged queens from monogynous colonies significantly heavier than such individuals from polygynous colonies $(F=368.09 ; \mathrm{df}=1 ; P<0.001 ;$ Fig. 1$)$. Finally, weights of these queens also were influenced significantly by their Pgm-3 genotypes $(F=40.01 ; \mathrm{df}=2 ; P<0.001)$ but the genotypic effect differed between the social 
671

Gene-

environment

effects on Fire

Ant phenotypes

(C) 1995 British

Ecological Society,

Functional Ecology,

9, 667-676

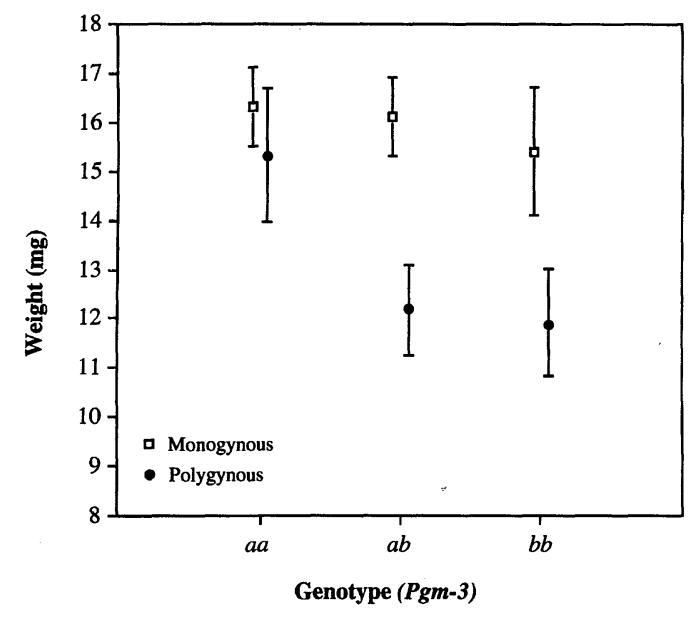

Fig. 1. Mean weight $( \pm 1 S D)$ of mature winged queens of the three $P g m-3$ genotypes collected from monogynous and polygynous colonies as they departed on mating flights. Samples sizes are: monogynous $P g m-3^{a / a}, n=122, N=16$; monogynous $\mathrm{Pgm}-3^{a / b}, n=98, N=15$; monogynous $\mathrm{Pgm}$ $3^{b / b}, n=10, N=3$; polygynous $P g m-3^{a / a}, n=6, N=3$; polygynous $P g m-3^{a / b}, n=629, N=35$; polygynous $P g m-3^{b / b}$, $n=222, N=33$, where $n$ indicates the number of individuals of a given genotype and $N$ the number of colonies from which they were collected.

forms as demonstrated by the significant interaction between genotype and social form $(F=41.68$; $\mathrm{df}=2$; $P<0.001)$. We therefore compared the weights of winged queens of the three genotypes separately for each social form.

Considering only monogynous colonies, there was again a significant effect of colony of origin $(F=6.09$; $\mathrm{df}=21 ; P<0.001)$ but no effect of $P g m-3$ genotype $(F=1 \cdot 16 ; \mathrm{df}=2 ; P=0 \cdot 32)$. Considering only polygynous colonies, there was an effect both of colony of origin $(F=9.52 ; \mathrm{df}=34 ; P<0.001)$ and genotype $(F=27.06 ; \mathrm{df}=2 ; P<0.001)$, with $P g m-3^{a / a}$ queens averaging $26 \%$ heavier than queens of the other two genotypes (Table 1, Fig. 1). The effect of genotype on the weight of winged queens varied among colonies, as demonstrated by the significant interaction between genotype and colony $(F=1.58 ; \mathrm{df}=34 ; P<0 \cdot 02)$. The weights of polygynous winged queens homozygous for $P g m-3^{a}$ were compared with the weights of monogynous winged queens of all three genotypes using a two-way nested ANOVA (colony nested in the social form). This analysis showed that such polygynous queens weighed significantly less than monogynous queens considered as a group $(F=10.71 ; \mathrm{df}=1$; $P<0.002$; see also Fig. 1).

To test whether the weight differences between polygynous winged queens of the different Pgm-3 genotypes arise during sexual maturation of the adults or whether they reflect different growth patterns during the larval stage, we compared the weights of queen pupae of the three genotypes in polygynous colonies (Table 1). A two-way ANOvA showed that pupal weight was influenced significantly by the colony of origin $(F=8.85 ; \mathrm{df}=17 ; P<0.001)$ but not by genotype $(F=0.514 ; \mathrm{df}=2 ; P=0.60)$, indicating that $P g m-3$ genotype has no discernible effect on the growth of queen larvae. The combined results from the different life stages therefore demonstrate that most or all of the weight differences between mature winged queens of the three genotypes in the polygynous form arise during sexual maturation of the adults.

\section{EFFECT OF QUEEN NUMBER}

We compared the weights of mature winged queens of different $P g m-3$ genotypes produced in monogynous and polygynous colony fragments to test the hypothesis that queen number, through its effect on colony pheromone level, influences the development of genotype-specific differences in individual reproductive phenotypes. A three-way ANOVA (using mean weight of each genotype in each fragment, see Materials and methods) was used to control for the variance associated with the colony of origin. As expected from previous studies (Keller \& Ross 1993a,b, unpublished data), the colony of origin had a significant effect on the weights of queens $(F=7 \cdot 36$; $\mathrm{df}=17 ; P<0 \cdot 001)$. There was also a significant effect of the type of colony fragment, with queens reared in the monogynous halves weighing more than queens of the same genotype reared in the polygynous halves $(F=8.67 ; \mathrm{df}=1 ; P<0.005$; Table 2$)$. Finally, queen weight also was influenced significantly by genotype $(F=59.15 ; \mathrm{df}=2 ; P<0.001)$, with queens homozygous for $P g m-3^{a}$ averaging $10-15 \%$ heavier than queens of the other two genotypes in both types of fragments (Table 2).

If the expressivity of $P g m$-3 (the magnitude of its phenotypic effects on queen reproductive physiology) is influenced by queen pheromone level in the natal colony, then there should be a significant interaction between genotype and type of colony fragment (monogynous or polygynous). However, no significant interaction between these two variables was found $(F=0.45 ; \mathrm{df}=2 ; \quad P=0.64)$, suggesting that queen number (pheromone level) is not a crucial component of the social environment responsible for the different phenotypic effects of the Pgm-3 genotypes in the polygynous form. Another way to examine this issue is to compare the weights of $P g m-3^{a / a}$ queens with the weights of queens of the two other genotypes for each pair of colony halves. If the higher pheromone level in polygynous field colonies is responsible for the smaller size of queens produced in these colonies, and if queens with the genotype Pgm$3^{a / a}$ are relatively less sensitive to this pheromonal effect, then there should be a greater difference in the weights of queens of different $P g m$ - 3 genotypes in the polygynous colony fragments than in the monogynous fragments. This was tested by comparing the weights of $P g m-3^{a / a}$ queens with those of queens of the other two genotypes between corresponding 
colony halves (again using mean weight of each genotype in each fragment). Queens of all three genotypes were produced in both halves of 11 of the 19 source colonies. In only five of the 11 pairs of fragments were there greater weight differences between Pgm$3^{a / a}$ and $P g m-3^{a / b}$ queens in the polygynous halves than in the monogynous halves, a pattern that does not depart significantly from the null expectation of equal numbers of polygynous and monogynous halves with the greater weight differences $(P>0.05)$. Similarly, in only six of the 11 pairs of fragments were weight differences between $P g m-3^{a / a}$ and $P g m-3^{b / b}$ queens greater in the polygynous halves than in the monogynous halves, a pattern that again does not depart significantly from the null expectation $(P>0.05)$.

\section{EFFECT OF BROOD/WORKER RATIO AND FOOD LEVEL}

We compared the weights of the mature winged queens of different Pgm-3 genotypes produced in the 'high brood', 'food limited' and 'control' fragments to test the hypothesis that low food availability to winged queens in polygynous colonies is the cause of the genotype-specific differences in queen reproductive phenotype in this social form. A three-way ANOVA was used to control for the variance associated with the colony of origin. The 'high brood' and 'food limited' treatments were compared separately with the 'control' treatment (as in previous comparisons, we use the mean weight of each genotype in each fragment).

There was a significant effect of altering the brood/worker ratio $(F=5.85 ; \mathrm{df}=17 ; P<0.001)$, with winged queens produced in fragments with elevated ratios generally weighing less than queens produced in control fragments (Table 3 ). There also were significant effects of colony of origin $(F=2.00 ; \mathrm{df}=15$; $P<0.05)$ and of genotype $(F=5.51 ; \mathrm{df}=2 ; P<0.01)$. However, there was no significant interaction between treatment and genotype $(F=5.45 ; \mathrm{df}=2$; $P<0.64$ ), suggesting that the manipulation of brood/worker ratios had no effect on Pgm-3 expressivity. The rarity of cases in which queens of all three genotypes were present in both the 'high brood' and 'control' fragments from a single source colony pre-

Table 1. Fresh weight $(\mathrm{mg} \pm \mathrm{SD})$ of mature adult winged queens and queen pupae from polygynous colonies

\begin{tabular}{llll}
\hline & \multicolumn{2}{l}{ Pgm-3 genotype } & \\
\cline { 2 - 4 } & $a a$ & $a b$ & $b b$ \\
\hline Adult winged queens & $15 \cdot 3 \pm 1 \cdot 3$ & $12 \cdot 2 \pm 0 \cdot 9$ & $11 \cdot 9 \pm 1 \cdot 1$ \\
& $n=6 ; N=3$ & $n=629 ; N=35$ & $n=222 ; N=33$ \\
Queen pupae & $15 \cdot 1 \pm 1 \cdot 3$ & $14 \cdot 6 \pm 1 \cdot 2$ & $14 \cdot 1 \pm 1 \cdot 2$ \\
& $n=20 ; N=8$ & $n=273 ; N=18$ & $n=132 ; N=18$ \\
\hline
\end{tabular}

$n$ indicates the number of individuals of a given genotype and $N$ the number of colonies in which they were found. cluded comparison of the weights of $P g m-3^{a / a}$ queens with those of other queens across such fragments.

Comparison of the 'food limited' and 'control' fragments showed a significant effect of genotype $(F=9.11 ; \mathrm{df}=2 ; P<0 \cdot 001)$ and an effect of the colony of origin that was nearly significant $(F=1 \cdot 76 ; \mathrm{df}=15$; $P=0.08)$. However, no effect of food deprivation could be detected $(F=0.511 ; \mathrm{df}=1 ; P=0.48)$, suggesting that this treatment had no influence on the weight of the queens produced or that it was too small to be detectable. [This analysis also showed no significant interaction between treatment and genotype $(F=1 \cdot 54 ; \mathrm{df}=2 ; P=0 \cdot 23)$, a result consistent with the lack of overall effect of the treatment.]

\section{DEGREE OF RECESSIVITY OF THE $P g m-3 a$ ALLELE}

Our previous studies (Ross 1992; Keller \& Ross 1993a) have suggested that the allele $P g m-3^{a}$ is completely recessive in its effects on queen phenotype and survival in the polygynous form; i.e. that $P g m-3^{a / b}$ and $P g m-3^{b / b}$ queens exhibit identical reproductive phenotypes and have equivalent probabilities of survival. Nonetheless, the intermediate ranking of heterozygotes with respect to some phenotypic traits in these earlier studies suggested that analysis of a larger data set, such as the one produced in this study, might allow more precise characterization of the degree of recessivity of $\mathrm{Pgm}-3^{a}$ (degree of dominance of $P g m-3^{b}$ ). This was accomplished by comparing the weights of $P g m-3^{a / b}$ and $P g m-3^{b / b}$ mature winged queens collected in the field using a two-way ANOVA. This analysis revealed that $P g m-3^{a / b}$ queens weighed significantly more than $P g m-3^{b / b}$ queens (Tables 1 and 4). There also was a significant effect of colony on the weight of winged queens and a significant interaction between genotype and colony (Table 4), indicating that the differential effects of these two genotypes on queen weight varied among the colonies. Comparison of weights of winged queens of the two genotypes produced in the experimental treatments where queen number, brood/worker ratio and food ration were manipulated gave similar results, with $P g m-3^{a / b}$ winged queens heavier on average than their $P g m-3^{b / b}$ counterparts (Tables 2 and 3). Because weights of queens are influenced by the type of colony fragment in which they were produced (see above), we analysed the data for each treatment separately. Table 4 shows that the effect of genotype was almost significant in two of the three treatments with small sample sizes ('high brood' and 'control') and significant in all other cases. As expected, there was a significant effect of the colony of origin in all cases and the interaction between genotype and colony of origin was significant as well in four cases.

This finding of a weight difference between Pgm$3^{a / b}$ and $P g m-3^{b / b}$ queens prompted us to reanalyse weight data from winged queens produced in experimental colonies in an earlier study $(n=35$ colonies, 
Gene-

environment

effects on Fire

Ant phenotypes $n=643$ individuals; Keller \& Ross 1993a). In that study we reported significant weight differences among queens of the three genotypes, with a nonparametric multiple-comparison (Scheffe) test showing significant weight differences only between the $P g m-3^{a / a}$ queens and queens of the other two genotypes (colony of origin could not be taken into account in this test). When these data were reanalysed using a two-way ANOVA to control for the effect of colony of origin, $P g m-3^{a / b}$ queens were found to be slightly but significantly heavier than $P g m-3^{b / b}$ queens $(11.2 \pm 1.2 \mathrm{mg}$ vs $11.1 \pm 1.1 \mathrm{mg} ; F=4.76 ; \mathrm{df}=1,576$; $P<0.05)$. The weight of queens in the earlier study again was influenced also by colony of origin $(F=8 \cdot 14 ; \mathrm{df}=34,576 ; P<0.001)$ but there was no significant interaction between genotype and colony of origin $(F=1.28 ; \mathrm{df}=31 ; P=0.64)$.

The combined data from these two studies indicate that the allele $P g m-3^{a}$ is not completely recessive in its effects on queen weight in the polygynous social form. The Dominance Index (D) developed by Wright (1934; see also Kacser \& Burns 1981) can be used to quantify the degree of dominance of the $P g m-3^{b}$ allele. Using the mean weight of polgynous winged queens of each of the three genotypes $\left(\mathrm{W}_{P g m-3^{a a}}\right.$, $\mathrm{W}_{P g m-3^{a b}}$ and $\mathrm{W}_{\left.P g m-3^{b /}\right)}$ as a measure of the phenotypic values, $\mathrm{D}$ is calculated as:

Table 2. Fresh weight ( $\mathrm{mg} \pm \mathrm{SD}$ ) of mature winged queens raised in monogynous and polygynous fragments of formerly polygynous colonies

\begin{tabular}{|c|c|c|c|}
\hline & \multicolumn{3}{|c|}{$P g m-3$ genotype } \\
\hline & $a a$ & $a b$ & $b b$ \\
\hline Monogynous fragments & $\begin{array}{l}13 \cdot 5 \pm 1 \cdot 2 \\
n=45 ; N=12\end{array}$ & $\begin{array}{l}12 \cdot 0 \pm 1 \cdot 0 \\
n=669 ; N=18\end{array}$ & $\begin{array}{l}11 \cdot 7 \pm 1 \cdot 2 \\
n=181 ; N=18\end{array}$ \\
\hline Polygynous fragments & $\begin{array}{l}13 \cdot 1 \pm 1 \cdot 0 \\
n=36 ; N=16\end{array}$ & $\begin{array}{l}11 \cdot 5 \pm 1 \cdot 0 \\
n=651 ; N=18\end{array}$ & $\begin{array}{l}11 \cdot 4 \pm 1 \cdot 0 \\
n=164 ; N=18\end{array}$ \\
\hline
\end{tabular}

$n$ indicates the number of individuals of a given genotype and $N$ the number of colony fragments in which they were found.

Table 3. Fresh weight $(\mathrm{mg} \pm \mathrm{SD})$ of mature winged queens raised in polygynous fragments with a high brood/worker ratio, in polygynous fragments with limited food and in polygynous control fragments

\begin{tabular}{llll}
\hline \multicolumn{3}{l}{ Pgm-3 genotype } & \\
\cline { 2 - 4 } & $a a$ & $a b$ & $b b$ \\
\hline High brood fragments & $12 \cdot 9 \pm 0 \cdot 9$ & $11 \cdot 7 \pm 1 \cdot 1$ & $10 \cdot 9 \pm 1 \cdot 6$ \\
& $n=9 ; N=4$ & $n=91 ; N=11$ & $n=24 ; N=10$ \\
Food limited fragments & $13 \cdot 2 \pm 1 \cdot 3$ & $11 \cdot 5 \pm 1 \cdot 3$ & $11 \cdot 1 \pm 1 \cdot 4$ \\
& $n=14 ; N=6$ & $n=101 ; N=14$ & $n=26 ; N=9$ \\
Control fragments & $12 \cdot 9 \pm 1 \cdot 4$ & $12 \cdot 0 \pm 1 \cdot 1$ & $11 \cdot 3 \pm 1 \cdot 1$ \\
& $n=15 ; N=6$ & $n=119 ; N=15$ & $n=39 ; N=9$ \\
\hline
\end{tabular}

$n$ indicates the number of individuals of a given genotype and $N$ the number of colony fragments in which they were found.
$\mathrm{D}=\frac{\mathrm{W}_{P g m-3^{\mathrm{b} / \mathrm{b}}-\mathrm{W}_{P g m-3^{\mathrm{a} / \mathrm{b}}}}}{\mathrm{W}_{P g m-3^{\mathrm{a} / \mathrm{b}}-\mathrm{W}_{P g m-3^{\mathrm{a} / \mathrm{b}}}}}$.

This index varies between 0 and 1 , with a value of 0 indicating complete dominance and a value of $1 \mathrm{com}$ plete codominance. Using weights of queens collected in the field yields a value of $\mathrm{D}=0 \cdot 10$. The same comparison using mean weights of the queens produced in the polygynous halves of the experimental laboratory colonies in Table 2 yields a value of $\mathrm{D}=0 \cdot 11$. Thus the allele $P g m-3^{b}$ exhibits high but incomplete dominance with respect to its effect on queen weight. An important point is that, because of the low value of $\mathrm{D}$ and the substantial noise introduced into the data from the colony-level effects, very large sample sizes were required to detect this incomplete dominance.

\section{Discussion}

This study confirms that there is a strong genotype by environment interaction affecting the weight (a correlate of reproductive development) of winged queens in the Fire Ant $S$. invicta. Mature winged queens with the homozygous genotype $P g m-3^{a / a}$ were on average $26 \%$ heavier than queens with the alternate genotypes in the polygynous social form. Furthermore, heterozygous queens were found to be somewhat heavier than $P g m-3^{b / b}$ queens, demonstrating that the allele Pgm$3^{a}$ is not completely recessive in its effect on queen weight in this social form (Dominance Index $=0 \cdot 10-0 \cdot 11)$. In contrast, no genotype-specific differences in the queen weight were observed in the monogynous social form, with winged queens of this form uniformly heavier than polygynous queens with the genotype $P g m-3^{a / a}$.

No difference in weight could be detected between $P g m-3^{a / a}$ queen pupae and queen pupae of the other two genotypes in the polygynous form, demonstrating that most or all of the genotype-specific weight differences in mature winged queens arise during sexual maturation of the adults. Similarly, cross-fostering experiments have revealed that the weight differences distinguishing winged queens of the two forms (independent of Pgm-3 genotype) are largely the product of the social organization (number of egg-laying queens) in the colony in which the winged queens mature as adults (Keller \& Ross 1993b). This suggests that some component of the social environment characteristic of polygynous colonies inhibits weight gains during the sexual maturation of winged queens and, furthermore, that $P g m-3^{a / a}$ queens are less susceptible to this factor than winged queens of the other two genotypes.

The weight of winged queens from laboratory colony fragments was significantly influenced by the number of egg-laying queens present during their maturation, with queens reared in monogynous fragments invariably heavier than queens of the same genotype reared in polygynous fragments. This result is consistent with the finding that mature winged 
674

L. Keller \&

K. G. Ross

Table 4. Analysis of variance comparing weights of $P g m-3^{a / b}$ and $P g m-3^{b / b}$ winged queens collected from polygynous field colonies and from experimental fragments of polygynous colonies maintained in the laboratory

\begin{tabular}{llll}
\hline & Effect of genotype & Effect of colony of origin & Genotype by colony interaction \\
\hline $\begin{array}{l}\text { Polygynous field colonies } \\
\begin{array}{c}\text { Monogynous experimental } \\
\text { fragments }\end{array}\end{array}$ & $F=3.98 ; \mathrm{df}=1 ; P<0.05$ & $F=10.63 ; \mathrm{df}=34 ; P<0.001$ & $F=1.56 ; \mathrm{df}=32 ; P<0.05$ \\
$\begin{array}{c}\text { Polygynous experimental } \\
\text { fragments }\end{array}$ & $F=5.84 ; \mathrm{df}=1 ; P<0.02$ & $F=9.38 ; \mathrm{df}=17 ; P<0.001$ & $F=1.28 ; \mathrm{df}=17 ; P=0.20$ \\
$\begin{array}{c}\text { High brood/worker ratio } \\
\text { experimental fragments }\end{array}$ & $F=2.94 ; \mathrm{df}=1 ; P=0.09$ & $F=5.54 ; \mathrm{df}=12 ; P<0 \cdot 001$ & $F=3.19 ; \mathrm{df}=7 ; P<0.005$ \\
$\begin{array}{c}\text { Food limited experimental } \\
\text { fragments }\end{array}$ & $F=4.64 ; \mathrm{df}=1 ; P<0.05$ & $F=3.98 ; \mathrm{df}=13 ; P<0.001$ & $F=6.24 ; \mathrm{df}=8 ; P<0.001$ \\
$\begin{array}{c}\text { Control experimental } \\
\text { fragments }\end{array}$ & $F=2.91 ; \mathrm{df}=1 ; P=0.09$ & $F=7.71 ; \mathrm{df}=15 ; P<0.001$ & $F=1.69 ; \mathrm{df}=8 ; P=0.11$ \\
\hline
\end{tabular}

Samples sizes are given in Tables 1-3.

queens collected from monogynous colonies in the field are significantly heavier than those collected from polygynous colonies, and that most of the weight difference arises from differential processes of maturation of the young adults in the two types of colonies. Thus the number of egg-laying queens, presumably acting through its effect on cumulative colony pheromone level, affects the maturation process of winged queens of all three Pgm-3 genotypes.

The two experiments designed to limit food availability to maturing queens in polygynous colonies gave contrasting results. Elevating brood/worker ratios affected the weight of the winged queens that were produced in the predicted fashion; these queens weighed less than queens in the control treatment. The treatment of restricting food to the colony fragments apparently had no effect on the weight of winged queens produced, for which there are several possible explanations. First, the reduction in the amount of food provided to each fragment might not have been sufficient to generate an effect. This hypothesis is unlikely because we observed a marked decrease in the amount of brood present in the fragments in this treatment, indicative of a general food shortage. Second, colony members might have regulated the quantity of brood reared and provisioned in order that the amount of food available to winged queens remained constant. Finally, workers in these fragments (and possibly in the other treatments as well) may have used some of their own stored fat reserves to supplement the feeding of winged queens. Indeed, there is evidence that workers in other ant species normally use their fat reserves to feed winged queens (Hasegawa 1993, unpublished data), and most of the weight increase of winged ant queens involves fat storage (Keller \& Passera 1989; Keller \& Ross 1993b). Under this hypothesis, the lower weight of winged queens reared in colonies with the high brood/worker ratios can be accounted for by workers using a greater proportion of their body reserves to feed the brood than in the controls, to the detriment of the winged queens.

Although polygyny inhibited weight gains by winged queens relative to monogyny, we observed no significant interaction between Pgm-3 genotype and queen number with respect to the weight of winged queens in experimental colony fragments, nor did we find a greater difference between the weight of $\mathrm{Pgm}$ $3^{a / a}$ queens and other queens in polygynous fragments than in monogynous fragments. These results fail to support the hypothesis that the expressivity of $P g m-3$ (the magnitude of its phenotypic effects on queen reproductive physiology) is influenced by queen pheromone level in the natal colony. Similarly, although increased brood/worker ratios significantly depressed the weights of winged queens produced, again there was no increase in the magnitude of the differential phenotypic effects of the Pgm-3 genotypes in the 'high brood' treatment relative to the controls.

There are two possible hypotheses for the observed lack of an effect of queen number and brood/worker ratio on Pgm-3 expressivity. First, the social environment in which queens spend the larval or pupal stage, rather than the social environment in which they mature as adults, is responsible for the differential phenotypic effects of the Pgm-3 genotypes in polygynous colonies. Queen pupae in our experiments all came from polygynous colonies, so they all would have experienced the identical relevant feature of the social environment that influences Pgm-3 expressivity under this hypothesis. Second, differential maturation processes of queens of alternate $P g m-3$ genotypes are influenced by components of the polygynous social environment other than those we considered in this study. As mentioned earlier, differences between the social forms in queen number and cumulative levels of queen-produced pheromones have a secondary effect on many colony characteristics, such as composition of the brood, and size and behaviour of the workers (Greenberg et al. 1985; Vargo \& Fletcher
Ecological Society, Functional Ecology, 9, 667-676 
Gene-

environment

effects on Fire
Ant phenotypes

1986a,b, 1987; Vargo 1992; Keller \& Nonacs 1993). It is possible that changes in any one of these correlated factors, rather than changes in the factors we actually manipulated, are responsible for the genotype-specific differences in processes of maturation of winged queens in polygynous colonies. Because it may take weeks for some of these correlated colony characteristics to respond completely to a change in colony pheromone level, and because each experimental treatment started immediately before the process of queen maturation commenced, it may be that the factor inducing genotype-specific maturation rates had not yet responded to the experimentally imposed change in pheromone level.

In conclusion, this study demonstrates that some component of the social environment characteristic of polygynous $S$. invicta colonies affects sexual maturation of winged queens, and that $P g m-3^{a / a}$, winged queens are less sensitive to this factor than are winged queens of the other two genotypes at this locus. Both manipulation of queen number (and presumably colony pheromone levels) and of brood/worker ratios resulted in significant changes in the weight of sexually mature winged queens, suggesting that these may be two of the factors responsible for the overall phenotypic differences between winged queens of the two social forms. However, neither of these factors could be shown to account for the genotype-specific phenotypic effects of Pgm-3 in polygynous colonies. These results demonstrate that the difference in expressivity of Pgm-3 in the two social forms is the result of factors other than those we considered or, alternatively, that it is owing to the influence of the social environment on an earlier developmental stage than we studied (e.g. the larval or pupal stage).

\section{Acknowledgements}

We thank François Bavaud, Koos Boomsma, Alan Grafen, Zoubeidi Toukif, Jacques Zuber and two anonymous referees for comments on the manuscript and statistical advice, and Beth Flaherty and Rhonda Seay for technical assistance. This work was funded by the Swiss National Science Foundation (grants no. 31-35584.92 and 31-36907.93 to L.K.) and the Georgia Agricultural Experiment Stations, University of Georgia.

\section{References}

Bradshaw, A.D. (1965) Evolutionary significance of phenotypic plasticity in plants. Advances in Genetics 13, 115-155.

Fletcher, D.J.C. (1986) Triple action of queen pheromones in the regulation of reproduction in fire ant (Solenopsis invicta) colonies. Advances in Invertebrate Reproduction 4 (eds M. Porchet, J.-C. Andries \& A. Dhaiant), pp. 305-316. Elsevier, Amsterdam.

(C) 1995 British Ecological Society, Functional Ecology, 9, 667-676 of dealation and oogenesis in virgin queen fire ants. Science 212, 73-75.
Fletcher, D.J.C., Cherix, D. \& Blum, M.S. (1983) Some factors influencing dealation by virgin queen fire ants. Insectes Sociaux 30, 443-454.

Greenberg, L., Fletcher, D.J.C. \& Vinson, S.B. (1985) Differences in worker size and mound distribution in monogynous and polygynous colonies of the fire ant Solenopsis invicta Buren. Journal of the Kansas Entomological Society 58, 9-18.

Hasegawa, E (1993) Caste specialization in food storage in the dimorphic ant Colobopsis nipponicus (Wheeler). Insectes Sociaux 40, 261-271.

Hedrick, P.W. (1986) Genetic polymorphism in heterogeneous environments: a decade later. Annual Review of Ecology and Systemtics 17, 535-566.

Jouvenaz, D.P., Allen, G.E., Banks, W.A. \& Wojcik, D. (1977) A survey for pathogens of fire ants, Solenopsis spp. in the southeastern United States. Florida Entomologist 60, 275-279.

Kacser, H. \& Burns, J.A. (1981) The molecular basis of dominance. Genetics 97, 639-666.

Keller, L. \& Nonacs, P. (1993) The role of queen pheromones in colonies of social insects; queen control or queen signal? Animal Behaviour 45, 787-794.

Keller, L. \& Passera, L. (1989) Size and fat content of gynes in relation to the mode of colony founding in ants (Hymenoptera; Formicidae). Oecologia 80, 236-240.

Keller, L. \& Ross, K.G. (1993a) Phenotypic basis of reproductive success in a social insect: genetic and social determinants. Science 260, 1107-1110.

Keller, L. \& Ross, K.G. (1993b) Phenotypic plasticity and cultural transmission of alternative reproductive strategies in the fire ant Solenopsis invicta. Behavioural Ecology and Sociobiology 33, 121-129.

Leigh Brown, A.J. (1977) Physiological correlates of an enzyme polymorphism. Nature 269, 803-804.

Moran, N.A. (1992) The evolutionary maintenance of alternative phenotypes. American Naturalist 139, 971-989.

Passera, L. \& Keller, L. (1990) Loss of mating flight and shift in the pattern of carbohydrate storage in sexuals of ants (Hymenoptera, Formicidae). Journal of Comparative Physiology B 160, 207-211.

Pfennig, D.W. (1992a) Proximate and functional causes of polyphenism in an anuran tadpole. Functional Ecology 6 , 167-174.

Pfennig, D.W. (1992b) Polyphenism in spadefoot toad tadpoles as a locally adjusted evolutionarily stable strategy. Evolution 46, 1408-1420.

Pfennig, D.W. \& Collins, J.P. (1993) Kinship affects morphogenesis in cannibalistic salamanders. Nature 362, 836-838.

Porter, S.D. (1992) Frequency and distribution of polygyne fire ants (Hymenoptera: Formicidae) in Florida. Florida Entomologist 75, 248-257.

Porter, S.D., Bhatkar, A., Mulder, R., Vinson, S.B. \& Clair, D.J. (1991) Distribution and density of polygyne fire ants (Hymenoptera: Formicidae) in Texas. Journal of Economical Entomology 84, 866-874.

Riddle, R.A., Iverson, V. \& Dawson, P.S. (1983) Dietary effects on fitness components at the $P G M-1$ locus of Tribolium castaneum. Genetics 103, 65-73.

Ross, K.G. (1992) Strong selection on a gene that influences reproductive competition in a social insect. Nature $\mathbf{3 5 5}$, 347-349.

Ross, K.G. (1993) The breeding system of the fire ant Solenopsis invicta: effects on colony genetic structure. American Naturalist 141, 554-576.

Ross, K.G. \& Fletcher, D.J.C. (1985) Comparative study of genetic and social structure in two forms of the fire ant Solenopsis invicta (Hymenoptera: Formicidae), and its 
L. Keller \&

K. G. Ross

evolutionary significance. Behavioral Ecology and Sociobiology 17, 49-356.

Ross, K.G. \& Keller, L. (1995) Joint influence of gene flow and selection on a reproductively important genetic polymorphism in the fire ant Solenopsis invicta. American Naturalist 146, 325-348.

Ross, K.G. \& Shoemaker, D. (1993) An unusual pattern of gene flow between the two social forms of the fire ant Solenopsis invicta. Evolution 47, 1595-1605.

Ross, K.G., Vargo, E.L. Keller, L. \& Trager, J.C. (1993) Effect of a founder event on variation in the genetic sexdetermining system of the fire ant Solenopsis invicta. Genetics 135, 843-854.

Shoemaker, D.D., Costa, J.T. \& Ross, G.K. (1992) Estimates of heterozygosity in two social insects using a large number of electrophoretic markers. Heredity 69, 573-582.

Stearns, S.C. (1992) The Evolution of Life Histories. Oxford University Press, Oxford.

Vargo, E.L. (1990) Social control of reproduction in fire ant colonies. Applied Myrmecology: a World Perspective (eds R. K. Vander Meer, K. Jaffe \& A. Cedeno), pp. 158-172. Westview Press, Boulder.

Vargo, E.L. (1992) Mutual pheromonal inhibition among queens in polygyne colonies of the fire ant Solenopsis invicta. Behavioural Ecology and Sociobiology 31, 205-210.

Vargo, E.L. \& Fletcher, D.J.C. (1986a) Evidence of pheromonal queen control over the production of male and female sexuals in the fire ant, Solenopsis invicta. Journal of Comparative Physiology A 159, 741-749.

Vargo, E.L. \& Fletcher, D.J.C. (1986b) Queen number and the production of sexuals in the fire ant, Solenopsis invicta. Behavioural Ecology and Sociobiology 19, 41-47.

Vargo, E.L. \& Fletcher, D.J.C. (1987) Effect of queen number on the production of sexuals in natural populations of the fire ant, Solenopsis invicta. Physiological Entomology 12, 109-116.

Vargo, E.L. \& Laurel, M. (1994) Studies on the mode of action of a queen primer pheromone of the fire ant Solenopsis invicta. Journal of Physiological Entomology 40, 601-610.

Via, S. \& Lande, R. (1985) Genotype-environment interaction and the evolution of phenotypic plasticity. Evolution 39, 505-522.

Wade, M.J. (1990) Genotype-environment interaction for climate and competition in a natural population of flour beetles, Tribolium castaneum. Evolution 44, 2004-2011.

West-Eberhard, M.J. (1989) Phenotypic plasticity and the origins of diversity. Annual Review of Ecology and Systematics 20, 249-278.

Wright, S. (1934) Physiological and evolutionary theories of dominance. American Naturalist 68, 24-53.

Received 26 September 1994; revised 11 January 1995; accepted 16 January 1995 